\title{
Performance Measurement in a South African Government Social Services Department: A Balanced Scorecard Approach
}

\author{
Chengedzai Mafini \\ Vaal University of Technology Department of Logistics, Republic of South Africa \\ Telephone: +27 169506883 (w) E-mail: chengedzai@hotmail.com \\ David Rabolane Isaac Pooe \\ Head of Department: Logistics Department, Vaal University of Technology \\ Faculty of Management Sciences, Republic of South Africa \\ Telephone: +27 169509520 (w) E-mail: pooe@vut.ac.za
}

Doi:10.5901/mjss.2013.v4n14p23

\begin{abstract}
We developed a Balanced Scorecard (BSC) questionnaire and used it to measure the performance of a South African government social services department. The quantitative survey approach was adopted in which a questionnaire was administered to a purposively recruited sample of 272 managers and employees of a South African government social services department. We used the four performance measures of the BSC, namely customer satisfaction, innovation and learning, internal processes and financial performance to develop the questionnaire. Data were analysed using the Statistical Packages for the Social Sciences (SPSS version 20.0). We employed simple descriptive statistics such as frequencies and percentages to determine performance in various strategic and operational areas within the department. We also used the mean score ranking technique to compare overall departmental performance based on the BSC indicators. Using the four performance indicators of the BSC, we were then able to establish performance levels in various areas of the department. Results of the study reveal that performance of the department was highest in five areas, namely promotion of good corporate ethics, service quality, ability to meet client demands, promotion of good corporate values and the fostering of good relations with other organisations. Performance was lowest in five areas, namely attrition of staff, divisional workload, corruption, work to employee ratio and the speed at which departmental programs are implemented. Among the four BSC performance indicators used in the study, performance was highest in two aspects, namely innovation and learning and customer satisfaction, with performance being lowest in internal processes.
\end{abstract}

Keywords: Performance Measurement, Balanced Scorecard, South Africa, organisational performance, social services department

\section{Introduction}

The performance of public sector organisations has emerged as a very critical subject throughout the post-1994 era in South Africa. Consequently, diverse perspectives on the ability of government departments to deliver quality service to the public have mushroomed from different strategic constituencies, in an attempt to find answers and solutions to performance related issues in the country (Tait \& Nienaber, 2010). However, despite these efforts, one dominant issue has been the manifest inability to identify and apply suitable performance measures, which has resulted in the failure to measure or manage organisational performance within the public sector (Nilsson, 2010). The issue is further exacerbated by the incidence of a cocktail of challenges that include inter alia a low institutional capacity, the limited involvement of stakeholders, high levels of corruption and informality that continue to dictate the fate of the sector (Schwella, 2001). It is also widely acknowledged that many public sector organisations in developing and emerging economies perform below the expected standards (Mankins \& Steele, 2005; Putu, Mimba, Van-Heden \& Tillema, 2007). This scenario presents an impetus to investigate means by which performance of public sector organisations can be measured, with a view of ultimately enhancing performance.

\section{Review of Related Literature}

\subsection{Organisational performance}

Organisational performance in the specific context of South Africa's public sector has received telescopic attention from a 
number of researchers (e.g. Van der Heijden \& Mlandi, 2005; Minnaar 2006; Ramseook-Munhurrun, Lukea-Bhiwajee, \& Naidoo, 2010). Organisational performance comprises the actual output or results of an organisation as measured against its intended outputs, or goals and objectives (Wery \& Waco, 2004; Short, Ketchen, Palmer, \& Hult, 2007; Pycraft, Singh, Phihlela, Slack, Chambers, \& Johnston, 2010). It is influenced by the nature and quality of both inputs and processes used in the organisation's transformation process (Janssen, 2000). When an organisation performs below the expected standard, the problem can be traced back to either one or more of the input resources, systems and/or the processes used to transform these resources into outputs (Gerhart, 2005). Generally, organisational performance can also be perceived as resulting from and being associated with a long list of contributing factors that include operational efficiencies, mergers, acquisitions, levels of diversification, organisational structures, top management team composition and style, human resource management, manipulation of the political and/or social influences intruding upon the market conformity to various interpretations of socially responsible behaviours, international or cross cultural activities of expansion and adaptation, and various other organisational and/or sectoral level phenomena (King, 2007). As such, solving the performance problem may entail implementing substantive and appropriate modifications to the identified problematic inputs, systems or processes and ensuring that there exists an appropriate fit or alignment between them in order to facilitate improved performance.

The subject of organisational performance can be addressed from either the private sector dimension or from the angle of the public sector (Carrim, 2009). Halachmi (2011) argues that the elaborate dichotomy between public sector organisations and commercial enterprises is that in the public sector, the profit motive does not exist, the potential for income generation is almost negligible and there is no agreed standard against which performance can ultimately be measured. A majority of public sector organisations also generate most of their income from the fiscus and are accountable to the taxpayer and government (Fryer, Antony \& Ogden, 2009). Consequently it was once considered impossible to measure performance in the public sector (Mcpherson, 2001). This probably explains why more recently, the language of performance has been associated with the establishment of standards to be achieved, and the audit of organisational systems to ensure conformance, signifying a paradigm shift from traditional measures of performance.

Public sector organisations approach performance issues from diverse angles and for a wide variety of reasons (Forlan \& Browne, 2005). For instance, in this sector, outstanding organisational performance signifies that the organisation is both effective and efficient in supplying public goods and services (Putu et al., 2007). Paranjape, Rossiter and Pantano (2006) also recognise that public sector performance is driven, in part, by organisational capacity, which we now understand as existing in basic areas such as strategic leadership, human resources, financial resources, infrastructure, programming and process management, and inter-institutional collaboration.

\subsection{Measurement of organisational performance}

Measurement of organisational performance is an intriguing topic. Performance measurement is the process of quantifying the efficiency and effectiveness of action (Neely, 2002). It may also be perceived as the process of creating a work environment or setting in which people are able to perform to the best of their abilities (Adcroft \& Willis, 2005). It includes activities that ensure that goals are consistently being met in an effective and efficient manner (Neely, 2002). Performance measurement can focus on the performance of an organisation, a department, employee, or even the processes to build a product or service, as well as many other areas (Langley, 2007). This seems to suggest that organisational performance and performance measurement are structurally interrelated. Performance measurement is tool for the enhancement of organisational performance, because it acts as a conduit through which management practitioners can identify areas where organisational performance is either poor or acceptable, thereby providing a platform for improvement.

There has been intense and unresolved debate on the criteria that can be used to measure organisational performance (Short et al., 2007). Performance indicators are often misunderstood, over-promoted, and accordingly misused to the extent that rhetoric has outdistanced practice by far in this area (Wery \& Waco, 2004). Most notably, devising indicators of good quality is a hard task (Langley, 2007). Moreover, due to the multi-faceted nature of the public sector, the assumption is that it is more challenging to develop measures in these organisations (Fryer et al., 2009). Van der Heijden \& Mlandi (2005) also establish the dilemmas of defining indicators in the public sector and conclude that the problems are not technical, but conceptual (what is the role of the public sector and what good performance is although they acknowledge that there are still problems with data quality.

Measurement of performance also presents the debate pertaining to what should be measured. While traditional models of performance have emphasised financial indicators of performance, a plethora of other indicators have either 
been developed or suggested (Callahan \& Gilbert, 2003). There is no universal agreement on which indicators are appropriate for a particular situation. For instance, in a study conducted by Richard, Mcmillan, Chadwick \& Dwyer (2009) 213 papers that focused on organisational performance were identified, making up $29 \%$ of the total published in several journals that were used in the research. Interestingly, overall, across the 213 papers identified as including a performance variable, 207 different measures of performance were used. Such an overwhelming diversity of approaches tends to complicate the whole process of performance measurement.

\subsection{Emergence of the balanced scorecard (BSC)}

As highlighted in the preceding paragraph, most conventional approaches to performance were mainly based on financial measures such as sales, gross margins, net profit margins, profit before interest and tax, profit before tax, profit after tax, inventory turnover, return on investment, return on capital employed, return on assets, return on equity, earnings per share and sales per employee (Richard et al., 2009). However, the over-emphasis placed on financial measures of performance triggered a number of groundbreaking studies by leading scholars during the 1990s as well as the early twenty first century (e.g. Lych \& Cross 1991; Kaplan \& Norton 1996; Brignall \& Modell, 2000; Kloot \& Martin, 2000). Two divergent perspectives subsequently emerged. The first view called for the immediate elimination of financial measures from all performance management frameworks (Houck, Speaker, Flemming \& Riley, 2012). The major reason given for this proposal was that while financial measures worked well for the industrial era, they were out of harmony with the skills and competencies required in the contemporary era (Muijs, 2011). The second perspective stressed that the solution was not to obliterate financial measures of performance but to use them in tandem with other measures of performance to create a synthesis of a better performance management system for practitioners (Rajesh, Pugazhendhi, Ganesh, Ducq \& Lenny-Koh, 2012. Kaplan and Norton (1996) of the Harvard Business School opted for the second perspective and used it as the premises for developing the Balanced Scorecard (BSC).

The BSC (Figure 1) has gained prominence as a performance measurement framework of choice for many management scientists and practitioners (Rajesh et al., 2012). The BSC is commonly identified as a first grade or state of the art performance measurement system (Richard et al., 2009; Serrat, 2010). Other management and organisational researchers (Kloot \& Martin, 2000; Janssen 2000; Brignall \& Modell, 2000) also support the BSC as a more appropriate strategic planning and performance management tool that can be used extensively in business and industry, government, and not for profit organisations worldwide to align business activities to the vision and strategy of the organisation, improve internal and external communications, and monitor organisation performance against strategic goals. Development of the BSC was triggered by the long-standing debate regarding financial and non-financial measures of performance (Ayesha \& Hussain, 2011). Instead of dropping financial measures, Kaplan and Norton (1996), argued that this problem can be overcome if a firm adopts a balanced set of measures. They then developed the BSC, an approach that allows managers to answer four fundamental questions namely;

1. How do we look to our shareholders (financial perspective)?

2. What must we excel at (internal business perspective)?

3. How do our customers see us (the customer perspective)?

4. How can we continue to improve and create value (innovation and learning perspective)?

Figure 1. Basic Balanced Scorecard

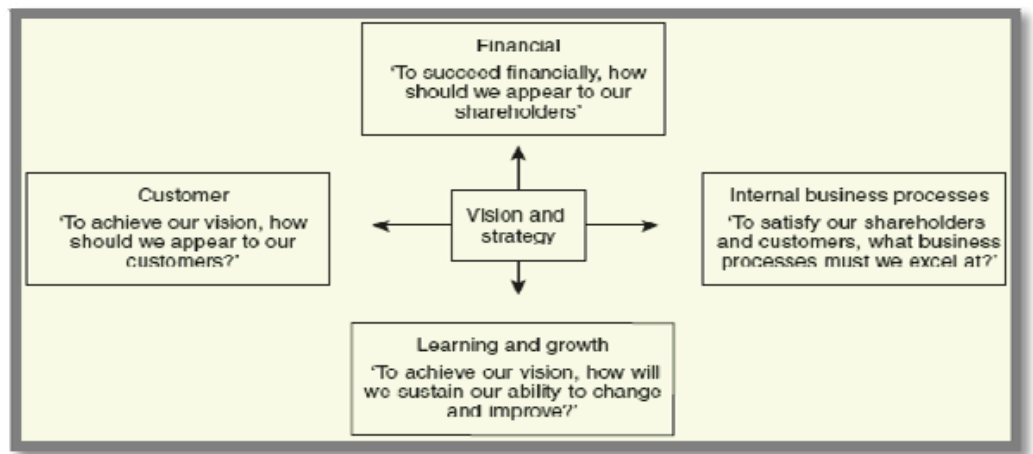

Source: Adapted from Kaplan and Norton (1996) 
Essentially, the basic BSC has remained unchanged, although the framework has somewhat evolved, with modern BSC designs notably having a number of features that clearly differentiate them from earlier examples (Mohamad, Lo \& La, 2009; Faroog \& Hussain, 2011). From the first one there have been the second, third, and more recently the fourth 'generations' of BSC design (Ioppolo, Saija \& Salomone, 2012). The latest versions of the BSC have linked the whole framework to strategy, and factored in certain measures that were not previously embedded in the original version: namely community and environment (including climatic change), IT portfolio management, brand value management and the value gap (the difference between the current value of the company and the share price of the organisation) (Serrat 2010). On the overall, the strength of the BSC exists in its ability to integrate different levels of business performance as well as the use of financial and non-financial, and internal and external measures as well as its adaptability to global dynamics as witnessed in the development of its latest transcriptions (Niven, 2003).

Despite its widespread acceptance in organisations, the BSC is not without criticism. Some of the earliest criticism from several scholars (e.g. Lingle \& Schieman 1996; Schneiderman, 1999; Malina, \& Selto, 2001) focused on technical flaws in the methods and design of the original BSC proposed by Kaplan and Norton. Other scholars (Norreklit, 2000; Papalexandris, Ioannou, Prastacos \& Soderquist, 2005) emphasise the lack of citation support for the BSC. Jensen (2001) also draws attention to the fact that the BSC is simply a list of loosely intertwined metrics that does not provide a standardised score or a unified view with clear recommendations. Furthermore, evidence reveals that many organisations in both the private as well as the public sectors struggle with the BSC (e.g. Chang, 2007; Schalm, 2008). Chang (2006) also provides a critique of the BSC in the health service and suggests that it is used more as an information system than a strategic performance measurement tool. Greatbanks and Tapp (2007) also report that a modified BSC was unsuccessfully used to manage performance in an Australian City Council.

Despite the avalanche of criticisms that it has received, the BSC still retains the support from researchers as well as management practitioners. Its originators (Kaplan \& Norton, 2004; Kaplan \& Norton, 2006) insist that in spite of its manifest imperfections, the BSC remains useful in all types of organisations as it facilitates the capture of financial and non-financial aspects of organisational performance and can therefore accommodate the more social and qualitative objectives of not-for-profit organisations. A number of studies (Sydney, 2004; Wynder, 2010; Farooq \& Hussain 2011; Houck et al., 2012) have also found the BSC to be a constructive performance management instrument in diverse settings. The fact that ample empirical support for the effectiveness of the BSC is available demonstrates that it remains an acceptable and dependable instrument for managing organisational performance in organisations.

\section{Problem Statement}

Organisational performance in the public sector has emerged as a very critical topic in the post-1994 era in South Africa (Nilsson, 2010). This is because most public organisations in the country have been unable to deliver a high standard of service to the public (Carrim, 2009). There has also been intense controversy the world over on criteria that are appropriate for measuring organisational performance (Callahan \& Gilbert, 2003). This debate stems from the fact that there are many performance measurement indices as well as frameworks that can be applied to measure performance in organisations. The presence of these multiple measurement mechanisms complicates the entire process of measuring as well as managing organisational performance.

Research evidence exists on the use of the BSC in the public sector in South Africa. For instance, Pienaar and Penzhorn (2000) examined use of the BSC to facilitate strategic management in an academic information service center at a South African government university. Sydney (2004) also successfully used the BSC to measure laboratory performance in a South African government laboratory. More recently, Julyan (2011) investigated the suitability the suitability of the BSC as a performance measurement tool for the South African government's upgrading of the Informal Settlements Programme. It is interesting through, to note that there is scant evidence of empirical research that specifically addresses the use of the BSC to measure the overall performance of a South African government social services department. The present study is intended to occupy this gap. Therefore, the purpose of the present study was to assess the use of the BSC a performance measurement tool in a South African government social services department. The study is significant in that its findings may provide management practitioners with scientific evidence on the efficacy of the BSC as a tool for performance measurement in public organisations in developing countries by providing a set of measures that are appropriate in such environments. 


\section{Materials and Methods}

\subsection{Participants}

In the present study, we adopted a quantitative approach in which we distributed a survey questionnaire to managers and employees of a South African government social services department. Respondents were recruited using the purposive sampling technique. In a purposive sample, the sample elements are selected because it is expected that they can serve the research purpose (Churchill \& Lacobucci, 2002). The criteria used to draw the sample was that the individual had to be based in Gauteng province, was available, was voluntarily willing to participate in the study and had been employed by the department for a period of at least two years.

\subsection{Questionnaire construction}

The questionnaire used in the survey was divided into two sections. Section A sought the respondents' demographic information. Questions on the demographics consisted of items that sought information pertaining to aspects such as the respondents' gender, age, highest level of professional qualification, number of years served in the organisation, and position occupied. Section B was composed of 33 questions that sought information on the performance of the organisation. These questions were based on the four perspectives of the BSC namely the Financial perspective, the Customer/Stakeholder perspective, the Internal Processes perspective, and the Learning and Growth perspective. One prerequisite for developing an effective BSC is that it must be adapted, or changed to fit a specific organisation (Pienaar \& Penzhorn, 2000). Therefore, the questions in the questionnaire were designed to reflect the strategic plan of the department, provide a framework that helps shape work behaviour, permit each person to measure his/her individual performance and give data to make changes immediately so that organisational performance is enhanced. The different dimensions of the BSC were scored on a 5 point Likert Scale with 1 expressing strongly disagree and 5 expressing strongly agree. The Likert scale was used as it is relatively easy to construct, makes data easy to collect and analyse, thereby making them suitable for surveys (Kothari, 2008). The respondents were requested to indicate their scores on this range in the scale.

To ascertain the validity of the instrument, fifteen of the draft questionnaires were pretested with a conveniently selected sample of respondents. In addition, the questionnaire was also reviewed by three academics who are experts in the field of performance management. Since the current study was a groundbreaking study as there are no other studies which have tested similar dimensions within the same context, which implies that there is no validated instrument which is already available, it was deemed necessary to pilot the questionnaire. A pilot study was therefore conducted using 50 respondents. Based on the feedback from the experts, the pretest and the pilot test, the researcher was able to factor in a number of minor revisions to the questionnaire. The eventual questionnaire was simpler, more accurate and more suitable for psychometric testing than the original questionnaire.

\subsection{Questionnaire administration}

After developing the questionnaires, we distributed 500 questionnaires to the identified sample of management and employees in the various offices of the social services department in Gauteng province. Questionnaires were administered with the assistance of a staff member in the department. We ensured that all respondents were well-briefed about the purpose of the study as well as other modalities used in the administration of the questionnaire. The questionnaires were administered in July 2012.

A covering letter was attached to the questionnaire to highlight the purpose of the study. In addition, a memorandum encouraging staff members to complete the questionnaire was written by the Director General of the department and emailed to all members of management and staff. In administering the questionnaire, various ethical considerations such as the participants' right to anonymity, confidentiality, privacy or non participation, informed consent and protection from discomfort, harm and victimisation were followed.

Among the 500 questionnaires that were initially distributed to respondents, 313 were returned. 41 questionnaires were eliminated in the screening process, which culminated in an eventual sample of 272 questionnaires, giving an acceptable return rate of $54 \%$. 


\subsection{Data analysis}

We used the Data the Statistical Package for the Social Sciences (SPSS version 20.0) to analyse the data. Reliability for the scale was measured using the Cronbach alpha coefficient. The scale attained a reliability of 0.72 , which is considered by Hair et al. (2010) as satisfactory. Frequencies, percentages and measures of central tendency (the mean score ranking technique) were employed to investigate the permutations within the questionnaire items.

\section{Demographic Information}

The demographic profile of respondents is illustrated in Table 1.

Table 1: Demographic Profile of Respondents

\begin{tabular}{lllll}
\hline Variable & Categories & N & n & $\%$ \\
\hline Gender & Males & 272 & 150 & 55.15 \\
& Females & 272 & 122 & 44.85 \\
\hline \multirow{2}{*}{ Age group } & 18-25 years & 272 & 23 & 8.46 \\
& 26-35 years & 272 & 135 & 49.63 \\
& 36-45 years & 272 & 75 & 27.57 \\
& 46-55 years & 272 & 29 & 10.66 \\
& Over 56 years & 272 & 10 & 3.68 \\
Number of years employed & Less than 2 years & 272 & 111 & 40.81 \\
& 2-5 years & 272 & 89 & 32.72 \\
& 6-9 years & 272 & 39 & 14.34 \\
& More than 9 years & 272 & 33 & 12.13 \\
\hline Type of Employment & Permanent & 272 & 223 & 81.99 \\
& Contract & 272 & 38 & 13.97 \\
& Part-time & 272 & 11 & 4.04 \\
\hline Highest academic qualification & Matric & 272 & 15 & 5.51 \\
& Certificate & 272 & 29 & 10.66 \\
& Diploma & 272 & 69 & 25.37 \\
& Degree & 272 & 117 & 43.01 \\
& Postgraduate degree & 272 & 40 & 14.71 \\
& Other & 272 & 2 & 0.74 \\
\hline & Executive Manager & 272 & 4 & 1.47 \\
& Senior Manager & 272 & 18 & 6.62 \\
& Middle Manager & 272 & 24 & 8.82 \\
& Line Manager & 272 & 48 & 17.65 \\
& Specialist Staff & 272 & 74 & 27.21 \\
& Clerical/ Administrative & 272 & 70 & 25.74 \\
& Other & 272 & 34 & 12.50 \\
\hline
\end{tabular}

An analysis of the demographic characteristics of respondents (Table 1) reveals that $55 \%$ ( $n=150)$ of respondents were male and 45\% ( $n=122)$ were female. A majority (58\%: $n=158)$ of the respondents were aged below 35 years. With regard to the number of years employed, approximately $74 \%(n=200)$ of the respondents had been employed in the department for a period of less than 5 years. On the type of employment, approximately $82 \%(n=223)$ of the respondents were under permanent employment within the department. At least $43 \%$ ( $n=117)$ of the respondents were holders of a first degree while approximately $15 \%(n=40)$ of the respondents were holders of a postgraduate degree. Among the respondents, 4 $(1.5 \%)$ were executive managers, 18 (7\%) were senior managers, $24(9 \%)$ were middle managers and $48(18 \%)$ were line managers. Furthermore, 74(27\%) were specialist staff, 70(26\%) were clerical or administrative staff and 34 (13\%) occupied other auxiliary positions such as internships, security and general work.

\section{Research Results}

By measuring organisational performance across four balanced perspectives, the BSC complements traditional financial 
indicators with measures for customers, internal processes, and innovation and improvement activities, which in turn must all be linked to the organisation's strategic vision (Kaplan \& Norton, 2006). Section B of the questionnaire consisted of 33 items that were designed to investigate the perceptions of management and staff at the department regarding performance of the department. Questions in this section were structured to elicit information based on four performance indicators of the BSC, namely:

- Customer satisfaction- (Items B1, B2, B3, B4, B6, B7, B8, B25, B31)

- Financial performance- (Items B19, B20, B21, B17, B18)

- Internal business processes- (Items B5, B9, B10, B14, B15, B16, B22, B23, B24, B26, B27, B28, B32, B33)

- Innovation and learning - (Items B11, B12, B13, B29, B30)

Table 2 is a statistical summary of the responses. Descriptive statistics, namely frequencies and percentages were used to analyse the data. In the information presented in tabular form, the numbers 1, 2, 3, 4 and 5 represent strongly agree, agree, neutral, disagree and strongly disagree, respectively. The frequencies are presented both numerically and as percentages that have been rounded off to one decimal place. To determine the areas in which the department has a stronger or weaker performance, the frequencies and percentages for all 33 items were placed in a rank order.

Table 2: Frequencies and percentages of organisational performance in rank order

\begin{tabular}{|c|c|c|c|c|c|}
\hline Item Item Description & $\begin{array}{c}\text { Strongly Agree } \\
(\%)\end{array}$ & $\begin{array}{c}\text { Agree } \\
(\%)\end{array}$ & $\begin{array}{l}\text { Neutral } \\
(\%)\end{array}$ & $\begin{array}{c}\text { Disagree } \\
(\%)\end{array}$ & $\begin{array}{c}\text { Strongly } \\
\text { Disagree (\%) }\end{array}$ \\
\hline B33 The department promotes good corporate ethics & $157(57.7)$ & $48(17.7)$ & $47(17.3)$ & $12(4.4)$ & $8(2.9)$ \\
\hline B7 The department offers quality service & 155(57.0) & 40(14.7) & $59(21.7)$ & $13(4.8)$ & $5(1.8)$ \\
\hline B1 The department is able to meet client demands & $153(56.3)$ & $35(12.8)$ & $58(21.3)$ & $17(6.3)$ & $9(3.3)$ \\
\hline B31 The department promotes good corporate values & $151(55.5)$ & $33(12.1)$ & $66(24.3)$ & $13(4.8)$ & $9(3.3)$ \\
\hline B24 The department relates well with other organisations & 149(54.8) & $46(16.9)$ & $62(22.8)$ & $10(3.7)$ & $5(1.8)$ \\
\hline $\begin{array}{l}\text { B23 The department has programs that support the } \\
\text { community }\end{array}$ & $145(53.3)$ & $54(19.9)$ & $55(20.2)$ & $15(5.5)$ & $3(1.1)$ \\
\hline B8 Delivery performance to clients is good & $143(52.6)$ & $33(12.1)$ & $69(25.4)$ & $23(8.5)$ & $4(1.5)$ \\
\hline $\begin{array}{l}\text { B9 Quality skills and expertise are available in the } \\
\text { department }\end{array}$ & 140(51.5) & $53(19.5)$ & $48(17.6)$ & $23(8.5)$ & $8(2.9)$ \\
\hline B19 Effective financial control measures are in place & $135(49.6)$ & $37(13.6)$ & $68(25.0)$ & $24(8.8)$ & $8(2.9)$ \\
\hline $\begin{array}{l}\text { B20 The overall financial performance of the department is } \\
\text { good }\end{array}$ & $131(48.2)$ & $35(12.9)$ & $90(33.1)$ & $12(4.4)$ & $4(1.5)$ \\
\hline B26 The department implements effective strategies & 131(48.2) & $31(11.4)$ & $81(29.8)$ & $22(8.1)$ & $7(2.6)$ \\
\hline B25 I am motivated on my job & $129(47.4)$ & $57(21.0)$ & $29(10.7)$ & $35(12.9)$ & $22(8.1)$ \\
\hline $\begin{array}{l}\text { B27 The policies and procedures in the department are } \\
\text { good }\end{array}$ & 129(47.4) & 29(10.7) & $80(29.4)$ & $25(9.2)$ & $9(3.3)$ \\
\hline $\begin{array}{l}\text { B11 I have the chance to participate in training and } \\
\text { development programs }\end{array}$ & $127(46.7)$ & $100(36.8)$ & $20(7.4)$ & $16(5.9)$ & $9(3.3)$ \\
\hline B32 The culture in the department is effective & 125(46.0) & $23(8.5)$ & $82(30.1)$ & $31(11.4)$ & $11(4.0)$ \\
\hline B13 Innovation is encouraged in the department & 122(44.9) & $45(16.5)$ & $58(21.3)$ & $30(11.0)$ & $17(6.3)$ \\
\hline $\begin{array}{l}\text { B14 Communication flows easily throughout the } \\
\text { department }\end{array}$ & 118(43.4) & 46(16.9) & $47(17.3)$ & $43(15.8)$ & 18(6.6) \\
\hline B2 Most clients are satisfied & $116(42.7)$ & $21(7.7)$ & 105(38.6) & \multirow{3}{*}{$\begin{array}{l}25+(9.2) \\
45(16.5) \\
34(12.5)\end{array}$} & $5(1.8)$ \\
\hline B12 The department adopts new technology regularly & 114(41.9) & $44(16.2)$ & $57(21.0)$ & & $12(4.4)$ \\
\hline B6 Feedback from clients is taken seriously & $114(41.9)$ & $42(15.4)$ & $75(27.6)$ & & $7(2.6)$ \\
\hline B4 The time taken to deliver services is quite acceptable & 114(41.9) & $21(7.7)$ & $83(30.5)$ & $41(15.1)$ & $13(4.8)$ \\
\hline $\begin{array}{l}\text { B21 The department is always able to meet its financial } \\
\text { goals }\end{array}$ & 112(41.0) & $21(7.7)$ & $119(43.8)$ & $19(7.0)$ & $1(0.4)$ \\
\hline B28 The level of wastage in the department is low. & $106(39.0)$ & $29(10.7)$ & $67(24.6)$ & $47(17.3)$ & $23(8.5)$ \\
\hline $\begin{array}{l}\text { B30 I have ample opportunities to make independent } \\
\text { decisions }\end{array}$ & 100(36.8) & $17(6.3)$ & $61(22.4)$ & $63(23.2)$ & $31(11.4)$ \\
\hline B17 Resources are managed efficiently & $100(36.8)$ & $17(6.3)$ & $95(34.9)$ & $41(15.1)$ & $19(7.0)$ \\
\hline $\begin{array}{l}\text { B18 The funds that are allocated to the department are } \\
\text { sufficient }\end{array}$ & 5) & $27(9.9)$ & 108(39.7) & $34(12.5)$ & $12(4.4)$ \\
\hline B3 Most clients are loyal to the department & $87(32.0)$ & $25(9.2)$ & 133(48.7) & $22(8.1)$ & $5(1.8)$ \\
\hline
\end{tabular}




\begin{tabular}{llllll}
\hline B29 There is good teamwork in the department & $87(32.0)$ & $15(5.5)$ & $120(44.1)$ & $32(11.8)$ & $18(6.6)$ \\
B15 Programs are implemented speedily & $83(30.5)$ & $17(6.3)$ & $22(8.1)$ & $90(33.1)$ & $60(22.1)$ \\
B5 The number of staff assigned to service client & $80(29.4)$ & $19(7.0)$ & $15(5.5)$ & $68(25.0)$ & $90(33.1)$ \\
$\quad \begin{array}{l}\text { requirements is sufficient } \\
\text { B22 The level of corruption in the department is low }\end{array}$ & $74(27.2)$ & $25(9.2)$ & $132(48.5)$ & $26(9.6)$ & $15(5.5)$ \\
B16 Divisions are not overloaded with activities & $58(21.3)$ & $25(9.2)$ & $68(25.0)$ & $106(39.0)$ & $15(5.5)$ \\
B10 The number of staff leaving the department is small & $44(16.2)$ & $25(9.2)$ & $51(18.8)$ & $121(44.5)$ & $31(11.4)$ \\
\hline
\end{tabular}

An analysis of Table 2 yielded three streams of observations related to the performance of the department. First, the social services department's performance was highest in five topical areas, namely promotion of good corporate ethics, service quality, ability to meet client demands, promotion of good corporate values and the fostering of good relations with other organisations respectively. Performance was lowest in five areas, namely attrition of staff, divisional workload, corruption, work to employee ratio, and the speed at which departmental programs are implemented. Third, the study was unable to establish the levels of performance in three areas, namely corruption levels, availability of teamwork and the loyalty of clients.

Among the 33 items on the questionnaire, promotion of good corporate ethics emerged as the highest performance area in the department. Approximately $75 \%(n=205)$ of the respondents either agreed or strongly agreed with the statement that the department promotes good corporate ethics. In a world that is full of ethical breeches by many officials in public organisations (Brody, 2012), it is noteworthy to attest that the department has adopted high standards of corporate behaviour. Studies conducted by a number of scholars (Elliot \& Thrash, 2001; Seijts \& Latham, 2005) draw attention to the existence of positive relationships between goal attainment and ethical behaviour. Performance goals may lead to high instances of unethical behavior when people fall short of these goals (Murdock \& Anderman, 2006). It is important then, that every organisation endeavors to consistently promote high ethical conduct among its management and employees. Therefore, the social services' department's modus operandi of promoting corporate ethics is likely to ensure that performance goals are attained in a clean and unquestionable manner.

Service quality scored the second and third highest points on the performance of the social services department. This finding illustrates the importance of service quality in influencing the performance of an organisation. Approximately $72 \%(n=195)$ of the respondents either agreed or strongly agreed with the statement that the department offers quality service. Furthermore, $69 \%(n=188)$ of the respondents either greed or strongly agreed that the department is able to meet client demands. This finding demonstrates that the department's management and employees perceive that the quality of service offered by the department is of a high standard. There is mounting pressure on public sector organisations to deliver quality services to their clients (Robinson, 2003). However, the quality of services provided by most public sector organisations world-wide is below standard as exhibited through their failure to meet the expectations of their clients (Teicher, Hughes \& Dow, 2002). It is also interesting to note that this finding represents the perceptions of departmental members rather than the views of the public. This being the case, there is a strong need to confirm this finding by conducting a follow up study to examine the perceptions of the department's clients on the quality of service provided by the department. However, the perceptions of internal stakeholders such as organisational members may still be regarded as valid insights on the matter (Ramseook-Munhurrun et al., 2010). It follows then, that the social services department appears to be one of the few public organisations in South Africa that is managing to meet client expectations, at least from an internal perspective.

Promotion of good corporate values came fourth on the performance rankings. Approximately $68 \%$ ( $n=184)$ of the respondents either agreed or strongly agreed with the statement that the corporate values that are promoted in the department are good. Corporate values are the philosophies or basic principles that direct the internal conduct of an organisation as well as its relationship with its internal and external stakeholders (Zairi \& Jarrar, 2000). This implies that corporate values are those qualities that an organisation holds as most important in doing its business. Empirical research (Osiyemi, 2006; Speculand \& Chaudhary, 2008) establishes that the corporate values of any organisation ultimately impact on organisational performance. The results of the current study demonstrate that corporate values in the department are of a superior quality. This then suggests that the performance of the department is likely to be correspondingly high, in line with its value system. This is dependant, though, on whether these values are implemented. Young (2011) opines that promotion of an effective value system does not necessarily imply that the promoted values are being implemented. As such, many organisations struggle and even fail to implement their values, leading to corporate failure (Hyde \& Williamson, 2000). Therefore, in as much as an effective corporate value system is promoted within the social services department, implementation of these values remains a separate issue that merits its own examination.

The social services department has managed to cultivate potent relationships with other organisations. This is 
illustrated by the fact that approximately $72 \%(n=195)$ of the respondents either agreed or strongly agreed with the statement that the department relates well with other organisations. Since no single organisation exists in isolation, it is important for every organisation to establish the right kind of relationships with other external organisations (McQuaid, 2009). The importance of mutually beneficial exchanges emanating from these inter-organisational partnerships cannot be underestimated. For instance, Radermacher, Karunarathna, Grace and Feldman (2011) suggest that well networked institutions post exceptional performance results, as coined by the popular phrase "partner or perish". The importance of forming alliances or global partnerships with other organisations has also gained momentum in recent years (Isoraite, 2009). Therefore, the results of the current study express that the department has performed well in establishing relationships with other organisations. This is likely to culminate in pertinent paybacks for the department, which ultimately enhance organisational performance.

The item labeled the 'number of staff leaving the department is small' was ranked lowest on the frequency distribution. Approximately $56 \%(n=152)$ of the respondents either disagreed or strongly disagreed with the statement that the number of staff leaving the social services department is small. This suggests that from the perspective of the respondents, the department is facing an unfortunate episode of high staff turnover. High staff turnover is an issue that most South African government organisations have been struggling to combat for several decades (Mdindela, 2009). Since the country is facing an acute shortage of critical skills, the employment tenure rate for most skilled people is limited as they are highly marketable (Gillingham, 2008). Naturally, the department has not escaped the overarching effects of this phenomenon. It is therefore paramount that the department initiates a human resource strategic plan that enables it to effectively select, retain, train and develop employees. Such a strategy is likely to boost both the intrinsic as well as the extrinsic motivation of staff, thereby reducing the rate of attrition within the department (Samuel \& Chipunza, 2009).

The extent to which the divisions within the social services department are overloaded with activities attained the second lowest position on the rankings of frequencies and percentages. Approximately $45 \%(n=121)$ of the respondents either disagreed or strongly disagreed with the statement that divisions within the department are not overloaded with activities. This finding signifies that the various divisions within the department are inundated with overbearing workloads. This finding dove-tails to the responses given to item B5 where respondents expressed that they were overloaded with work. As such, the overloading of individual employees is a microcosm of the overburdening workload that various divisions within the department have to carry. High divisional workload could be a result of a number of challenges that the organisation faces. It could be that the department has failed to respond to an exponential rise in the number of clients (Ismail \& Alsadi, 2010). There could also be oversights in the proper allocation of tasks among divisions (Robinson, Feinerman \& Franks, 2009). Furthermore, the problem may also stem from other internal structural inefficiencies such as bureaucracies and red-tape (Monsod, 2009; Qahtani, 2012). In all cases, divisional overload is dysfunctional to the social services department and has to be minimised.

The prevalence of corruption within the social services department achieved the third lowest position on the rankings of frequencies and percentages. Approximately $49 \%(n=132)$ of the respondents expressed neutrality to the statement that the level of corruption in the department is low. Interestingly, approximately $36 \%(n=99)$ of the respondents either agreed or strongly agreed with the statement whereas approximately $15 \%(n=41)$ of the respondents either disagreed or strongly disagreed with the statement. These results point to the fact that a majority of respondents were not sure on the levels of corruption within the department. This scenario is precarious because it is difficult initiate appropriate measures to address a phenomenon which the people on the ground are not aware of. Nevertheless, corruption within public organisation is generally endemic. The Department of Public Service and Administration (2002) chronicles that corruption in South Africa manifests itself in public service and society through bribery, embezzlement, fraud, extortion, abuse of power, favouritism, nepotism, insider trading and conflict of interest. Naturally, an organisation will not prosper if these vices are not curtailed (Wu, 2010). Gauteng Provincial Government (2009) also throws spotlight on the fact that the South African government has adopted a strong exception to corrupt practices and regards the matter very seriously because of the potential damage that this could cause to the country's economy and reputation globally. Therefore, need exists to establish the correct level of corruption within the social services department and to take appropriate measures which ensure that such corporate improprieties are eliminated.

The sufficiency of number of staff assigned to service client requirements attained the fourth lowest position on the rankings of frequencies and percentages. Approximately 58\% (158) of the respondents either disagreed with the statement that the number of staff assigned to service client requirements is sufficient. This denotes that the workload per staff member is overwhelming, as each employee has to deal with a large number of clients. However, the effects of such work overload are well documented in literature. Tahir, Yusoff, Azam, Khan and Kaleem (2012) found that the 
performance of employees is negatively affected by high work overload, which also directly affects customer satisfaction. Greenberg, Sikora, Grunberg and Moore (2006) also concluded that the performance of work teams is wholly or partially mediated through perceptions of personal mastery, work overload and job satisfaction. This is ostensibly because work overload leads to job strain by exhausting the employees' mental and physical resources, thereby leading to the depletion of energy, which renders the employee unable to perform at optimum abilities (Bakker \& Demerouti, 2006). It may be suggested then, that overall performance of the employees at the social services department could be enhanced if the issue of work overload is addressed holistically.

The speed at which programs are implemented achieved the fifth lowest position on the rankings of frequencies and percentages. Approximately $55 \%(n=150)$ of the respondents either disagreed or strongly disagreed with the statement that programs are implemented speedily within the social services department. This suggests that departmental programs are implemented at a slow pace, which is not satisfactory. Empirical research reinforces that the scheduling and timing of organisational programs is instrumental in determining the success of that particular program (University of New Mexico, 2011). Organisations benefit enormous rewards when strategies are implemented rapidly rather than sluggishly (Bloodgood \& Morrow Jr, 2003). Fontannaz and Oosthuizen (2008) also posit that the speed at which strategy is executed is a formidable performance indicator. Accelerating organisational speed yields pay offs in such areas as organisational agility (adaptability), overcoming organisational inertia, organisational responsiveness and change implementation, among others (Alzoubi, Al-otoum \& Albatainh, 2011). Therefore, the social services department stands to realise these benefits should its organisational speed be enhanced.

To establish the overall performance of the department the four BSC performance measures were ranked in terms of their mean scores. Table 3 is a summary of the reliabilities and the mean scores of the performance indicators.

Table 3: Reliabilities and Mean Score Summaries for the BSC Performance Measures

\begin{tabular}{lcccc}
\hline Performance Indicator & Number of Items & Reliability (Cronbach Alpha) & Mean Score & Position on the Mean Score Rank \\
\hline Customer Satisfaction & 9 & 0.835 & 4.575 & 2 \\
Financial Performance & 5 & 0.754 & 4.460 & 3 \\
Internal Processes & 14 & 0.851 & 4.396 & 4 \\
Innovation and Learning & 5 & 0.762 & 4.632 & 1 \\
\hline
\end{tabular}

On the basis of the mean scores computed for each performance measure (Table 3$)$, innovation and learning $(\bar{x}=4.632)$ was ranked highest, followed by customer satisfaction $(\bar{x}=4.575)$, financial performance $(\bar{x}=4.460)$ with internal processes trailing $(\bar{x}=4.396)$ the list. The mean scores for the four performance measures indicate an average scoring between 'agree' and 'strongly agree' on the Likert Scale. These findings demonstrate that among the four BSC measures, performance with regard to innovation and learning is the highest within the department and lowest in internal processes.

\section{Conclusions}

The purpose of the study was to use a BSC-based questionnaire to measure the performance of a South African government social services department. The study provides further evidence that when used appropriately, the BSC can be a valuable tool for measuring the performance of a public organisation, and more specifically, a social services government department. Organisational performance at the social services department was measured using a 33-item scale that was based on the four performance measures of the BSC, namely customer satisfaction, financial performance, internal business processes and innovation and learning. Using the approach, it was possible to determine the performance of the department, which proved to be satisfactory in most regards, based on the fact that a majority of responses on all items on the scale were found between the 'agree' and 'strongly agree' anchors on the Likert scale.

Among the four BSC performance measures used in the study, performance was highest in two aspects, namely innovation and learning and customer satisfaction, with performance being the least potent in internal processes. In terms of individual questionnaire items, the department registered pleasing performance in a several areas such as the prudent and efficient management of financial and other resources, regular adoption of new technologies, entrenchment of an innovation culture, availability of training and development platforms to departmental members, development of appropriate and effective policies and procedures for the department, acceptable levels of staff motivation, establishment of community development programs and availability of quality human skills and expertise in the department. Poor 
performance was observed in a number of areas, namely high staff turnover levels, overloading the divisions with work activities that they are not able to cope with, a sluggish implementation of departmental programs, and an inadequate numbers assigned to service client requirements.

The study did not manage to establish performance in three relevant areas, namely corruption levels, availability of teamwork and the loyalty of clients. The lack of clarity in these areas stems from the fact that a majority of respondents answered 'neutral' in their responses to the questions related to these items.

\section{Recommendations}

The findings of the study suggest that there are several challenges that need to be addressed by the social services department with regard to its performance. We recommend the following strategies, which may be helpful in meeting the identified challenges.

To reduce the high staff turnover that is currently being experienced, it is necessary to conduct an investigation into the causes of this turnover and its effects to the social services department. For instance, there is need to establish whether this turnover is functional or dysfunctional to the department. Turnover can have intrinsic benefits, as incoming workers may be more highly motivated, better educated and more highly skilled than those they replace (Brown, Garino \& Martin, 2009). As such, only when these causes of turnover in the department have been have been established, and their effects identified, can appropriate solutions be found. Any other approach may lead to the prescription of ineffective and unnecessary strategies, which may eventually prove to be very costly to the department (Mbah \& Ikemefuna, 2012).

Currently, inadequate numbers of staff are assigned to service client requirements. This could account for the high work overload being experienced in the divisions. Prima facie evidence seems to link the challenge to a lackluster and ineffective human resource planning mechanism in the social services department, which has left the entire organisation devoid of adequate levels of employees to man all workstations and to meet daily work demands. It is therefore recommended that the human resource planning apparatus be revamped. When implemented properly, human resources planning will provide knowledge of know how many people and what sort of people the department should have in order to meet present and future business requirements (Armstrong, 2010). It will holistically encompass all key performance components of human resources management that include inter-alia, creating an employer brand, retention strategy, absence management strategy, flexibility strategy, talent management strategy, recruitment and selection strategy (Thorne \& Pellant, 2007). Therefore, if this aspect of human resources is overhauled, the challenges related to overload may be reduced significantly.

In order to speed up the rate at which departmental programs are implemented, best practice that includes strategies such as recruiting fast employees, continuous adoption of new technology, streamlining organisational processes, reducing barriers to speed and benchmarking may be implemented (Sullivan, 2011).

\section{Limitations and Implications for Further Research}

The current study provided a number of useful insights on the use of the BSC as an instrument for performance measurement in a public organisation. However, despite the efforts made by the researchers to ensure that the study is without flaws, there are several constraints that need to be highlighted so that they can be addressed in the future. First, the findings of the study were restricted to a small sample size of 272 respondents who were based in one geographic location, namely Gauteng Province. Therefore, caution should be exercised regarding the direct generalisation of the findings to other contexts and regions in the country and beyond (Babbie \& Mouton, 2007). Second, it was not possible for the researcher to control how the respondents completed the questionnaires. Consequently, respondents completed the questionnaires at their own time and in the absence of the researcher. Greater accuracy could have been achieved if the questionnaires had been completed in the presence of the researcher and his assistants. This was not possible because the researcher did not have access to the offices and workstations within the department premises, where entry is restricted and controlled. Third, we acknowledge the study's reliance on descriptive statistics as the primary data analysis vehicle.

The current study is not without implications for further research. The scope of the study could be expanded to include other public organisations as well as other regions within the country. In the current study, data were collected from internal stakeholders namely management and employees from the department. The results could be more informative if the views of both internal and external stakeholders were included and compared. This presents the need for conducting similar studies using perceptions of other external stakeholders such as the clients. 
The current study was conducted using the quantitative methodology. It could be interesting to conduct a similar study using the triangulation method, which integrates both quantitative and qualitative methods. This posture could ensure that there are trade-offs between the strengths and shortcomings of the two methods, thereby boosting the validity of the results (Bogdan \& Biklen, 2006).

In the current study, two paradoxes emerged, which merit further empirical introspection. First, results of the study reveal that although the motivation of departmental members in the department is sufficiently high, staff turnover is also high, which is unusual. Second, although the findings of the study found that the department scores highly in terms of customer satisfaction, the same findings also reveal that a majority of respondents (59\%; $n=160)$ either disagree or are not sure whether the department's clients are loyal or not. Further studies into these two paradoxical scenarios could provide interesting insights on how an organisation that has supposedly motivated individuals can also record high attrition levels, and how the same organisation could have satisfied clients of which a majority may not be loyal to that organisation. Studies could also be conducted to establish the accurate levels of corruption as well as teamwork in the department, since these could not be established in the study. This could facilitate appropriate action meant to either restrain corruption levels in the department by keeping them at a minimum or to enhance the levels of teamwork.

\section{References}

Adcroft, A., \& Willis, R. (2005). The (un)intended outcome of public sector performance measurement. International Journal of Public Sector Management, 18(5), 386-400.

Alzoubi. A, E, H., Al-otoum, F, J., \& Albatainh, A. K. F. (2011). Factors affecting organization agility and product development. International Journal of Research and Reviews in Applied Sciences, 9(3), 503-516.

Armstrong, M. (2010). Essential human resource management practice. London: Kogan Page.

Babbie, E. \& Mouton, J. (2007). The practice of social research: South African edition. Oxford: Oxford.

Bakker, A. B., \& Demerouti, E. (2006). The Job Demands-Resources model: state of the art. Journal of Managerial Psychology, 22(3), 309-328.

Bloodgood, J. M., \& Morrow JR, J. L. (2003). Strategic organizational change: Exploring the roles of environmental structure, internal conscious awareness and knowledge. Journal of Management Studies, 40, 71761-1782.

Bogdan, R. C., \& Biklen, S. K. (2006). Qualitative research in education: an introduction to theory and methods. London: Allyn \& Bacon.

Brignall, S., \& Modell, S. (2000). An institutional perspective on performance measurement and management in the 'new public sector'. Management Accounting Research, 2000 (11), 281-306.

Brody, S. H. (2012). Why public integrity fails: "The fault...is not in our stars, but in ourselves". Journal of Academic and Business Ethics, 6, 1-16.

Brown, S., Garino, G., \& Martin, C. (2009). Firm performance and labour turnover: evidence from the 2004 workplace employee relations survey. Economic Modeling, 26, 689-695.

Callahan, R. F., \& Gilbert, G. R. (2003). Design features of public agencies and their relationship with end user satisfaction. Cape Town. University of Cape Town Press.

Carrim, Y. (2009). Addressing the financial challenges in municipalities in the context of a review of the local government model. Keynote address of the Deputy Minister of Cooperative Governance and Traditional Affairs to the Institute of Municipal Finance Officers Annual Conference, Johannesburg, 6 / 10/2009. [online]. Available at: http://www.cogta.gov.za/index.php/news/174-yunus-carrim/264-financialchallenges-in-context-of-review-of-Ig-model-imfo-conference-6-oct-09.html. (11 November 2010).

Chang, H. (2006). Development of performance measurement systems in quality management organisations. The Service Industries Journal, 26 (7), 765-86.

Chang, A. (2007). Balanced Scorecard Implementation in the Public Sector: Lessons Learnt in a Large Local government Authority. [online]. Available at: http://www.afaanz.org/openconf/2009/modules/request.php?module=0c_program\&action=view.php\&id=228 (6 October 2011).

Churchill, G. A., (Jr) \& Lacobucci, D. (2002). Marketing research: Methodological foundations. $8^{\text {th }}$ ed. Fortworth: Harcourt College Publishers.

Department of Public Service and Administration. (2002). Public service anti-corruption strategy.[online]. Available at: http://www.homeaffairs.gov.za/PDF/Public\%20Service\%20Anti corruption\%20Strategy-1.pdf. (8 October 2012).

Elliot, A., \& Thrash, T.M. (2001). Achievement goals and the hierarchical model of achievement motivation. Educational Psychology Review, 13, 139-156.

Farooq, A., \& Hussain, Z. (2011). Balanced scorecard perspective on change and performance: a study of selected Indian companies. Procedia Social and Behavioral Sciences, 24, 754-768

Fontannaz, S., \& Oosthuizen, H. (2008). Performing at speed. University of Stellenbosch Leaders Lab. August. [online]. Available at: http://www.usb.ac.za/ Media/ thought leadership/ leaders' lab/ performing at speed.Pdf. (10 August 2012).

Forlan, P., \& Browne, J. (2005). A review of performance measurement: towards performance management. Computers in Industry, 56, 663-680.

Fryer, K., Antony, J., \& Ogden, S. (2009). Performance management in the public sector. International Journal of Public Sector Management, 22 (6), $478-498$.

Gauteng Provincial Government. (2009). Anti-corruption strategic framework. [online]. Available at: http://www.gautengonline.gov.za /Publications/anti\%20corruption\%20report.pdf. (10 August 2012).

Gerhart, B. (2005). Human resources and business performance: findings, unanswered questions, and an alternative approach. Management Review, 16, 174-85.

Gillingham, A. (2008). Skills and clientele vanish. Sunday Times, 28 September, p. 17.

Greatbanks, R., \& Tapp, D. (2007). The impact of balanced scorecards in a public sector environment: empirical evidence from Dunedin City 
Council, New Zealand. International Journal of Operations \& Production Management, 27 (8), 846-73.

Greenberg, E. S., Sikora, P. B., Grunberg, L., \& Moore, S. (2006). Work Teams and Organizational Commitment: exploring the Influence of the Team Experience on Employee Attitudes. Workplace Change Project Working Paper WP-012. [online]. Available at: http://www.colorado.edu/ibs/PEC/workplacechange/papers/WP_012.pdf. (10 August 2012).

Hair, J. F., Black, B., Babin, B., Anderson, R. E., Tatham, R. L., \& Black, W. C. (2010). Multivariate data analysis: a global perspective. NY: Pearson Education Inc.

Halachmi, A. (2011). Imagined promises versus real challenges to public performance management. International Journal of Productivity and Performance Management, 60 (1), 24-40.

Houck, M. Speaker, P. J., Fleming, A. S., \& Riley Jr, R. A. (2012). The balanced scorecard: sustainable performance assessment for forensic laboratories. Science \& Justice, 52 (4), 209-216.

Hyde, P., \& Williamson, B. (2000). The importance of organisational values Part 3: choosing and implementing organisational values. Focus on Change Management, 68, 10-14.

Ioppolo,G., Saija, G., \& Salomone, R. (2012). Developing a territory Balanced Scorecard approach to manage projects for local development: Two case studies. Land Use Policy, 29 (3), 629-640.

Ismail, S. T., \& Alsadi, B. Y. (2010). Relationship marketing and organizational performance indicators, European Journal of Social Sciences, 12 (4), 545-557.

Isoraitè, M. (2009). Importance of strategic alliances in company's activities. Intellectual Economics, 1(5), 39-46.

Janssen, O. (2000). Job-demands, perceptions of effort-reward fairness, and innovative work behavior. Journal of Occupational and Organizational Psychology, 73 (1), 287-302.

Jensen, M. C. (2001). Value maximization, stakeholder theory, and the corporate objective function. Journal of Applied \& Corporate Finance, 14 (3), 221-241.

Julyan, L. (2011). The Balanced Scorecard as a performance measurement tool for the South African government's upgrading of informal settlements programme. Doctoral thesis. Pretoria: University of South Africa.

Kaplan, R. S., \& Norton, D. P. (1996). The balanced scorecard: translating strategy into action. Boston, MA: Harvard Business School Press.

Kaplan, R. S., \& Norton, D. P. (2004). Strategy maps: converting intangible assets into tangible outcomes. Boston, MA: Harvard Business School Press.

Kaplan, R.S., \& Norton, D. P. (2006). Alignment: using the Balanced Scorecard to create corporate synergies. Boston, MA: Harvard Business School Press

Kloot, L., \& Martin. J. (2000). Strategic performance management: a balanced approach to performance management issues in local government. Management Accounting Research, 11, 231-251.

Kothari, C. R. (2008). Research methodology: methods and techniques. $2^{\text {nd }}$ ed. New Delhi: New Age International.

Langley, A. (2007). Process thinking in strategic organization. Strategic Organization, 5 (3), 271-282.

Lingle J. H., \& Schieman W. A. (1996). From Balanced Scorecard to strategic gauges: is measurement worth it. Management Review.85, 85-106.

Lynch, R., \& Cross, K. (1991). Measure up — the essential guide to measuring business performance. London: Mandarin.

Malina, M. A., \& Selto, F. H. (2001). Communicating and controlling strategy: an empirical study of the effectiveness of the Balanced Scorecard. Journal of Management Accounting Research, 13, 47-61.

Mbah, S. E., \& Ikemefuna, C. O. (2012). Job satisfaction and employees' turnover intentions in total Nigeria plc. in Lagos State. International Journal of Humanities and Social Science, 2 (14), 275- 287.

Mankins, M.C., \& Steele, R. (2005). Turning great strategy into performance. Harvard Business Review: 65-72, July -August.

McQuaid, R. W. (2009). Theory of organisational partnerships - partnership advantages, disadvantages and success factors. In: The New Public Governance: emerging perspectives on the theory and practice of public governance. Routledge, Edinburgh: 127-149.

Mcpherson, M. (2001). Performance measurement in not-for profit and public sector organisations .Measuring Business Excellence, 5 (2), $13-17$.

Mdindela, S.V. (2009). Staff turnover at selected government hospitals. Masters dissertation submitted to Nelson Mandela Metropolitan University, Port Elizabeth, South Africa. [online]. Available at: http://www.nmmu.ac.za/documents/theses/sindiwsa \%20victoria\%20mdindela.pdf. (11 August 2012).

Minnaar, F. (2006). Integrated performance management: The evolving South African management Model. Journal of Public Administration, $41(21), 177-190$

Mohamad, A. A., Lo, M., \& La, M. (2009). Human resource practices and organizational performance. incentives as moderator. Journal of Academic Research in Economics, 1 (2), 229-244.

Monsod, T. C. (2009). The Philippine bureaucracy: incentive structures and implications for performance. HDN Discussion Paper Series No 4. [online]. Available at: http://hdn.org.ph/wp-content/uploads/2009/05/dp04_monsod.pdf. (10 August 2012).

Muijs, D. (2011). Leadership and organisational performance: from research to prescription. International Journal of Management, 25 (1), $45-60$.

Murdock, T. B., \& Anderman, E. M. (2006). Motivational perspectives on student cheating. Toward an integrated model of model academic dishonesty. Educational Psychologist, 41, 129-145.

Neely, A. (2002). Business performance measurement: theory and practice. Cambridge: University of Cambridge.

Nilsson, J. (2010). What's the problem? local officials' conceptions of weaknesses in their municipalities' crisis management capabilities. Journal of Contingencies and Crisis Management, 18 (2), 83-95.

Niven, P. R. (2003). Balanced Scorecard: Step-by-step for government and non-profit agencies. New Jersey: John Wiley \& Sons.

Norreklit H. (2000). The balance on the Balanced Scorecard - a critical analysis of some of its assumptions, Management Accounting Research, $11,65-88$

Papalexandris, A., Ioannou, G., Prastacos, G.P., \& Soderquist, K.E. (2005). An integrated methodology for putting the Balanced Scorecard into action. European Management Journal, 23 (2), 214-227.

Paranjape, B., Rossiter, M., \& Pantano, V. (2006). Insights from the Balanced Scorecard performance measurement systems: success, failures and future - a review. Measuring Business Excellence, 10 (3), 4-14. 
Pienaar, H., \& Penzhorn, C. (2000). Using the Balanced Scorecard to facilitate strategic management at an academic information service center. Libri, 50, 202-209.

Putu, N. I., Mimba, S. H., Van Heden, J., \& Tillema. S. (2007). Public sector performance measurement in developing countries: a literature review and research agenda. Journal of Accounting and Organisational Change, 3(3), 16-17.

Pycraft, M., Singh, H., Phihlela, K., Slack, N., Chambers, S., \& Johnston, R. (2010). Operations management: global and Southern African perspectives. $2^{\text {nd }}$ ed. Cape Town: Pearson Education.

Qahtani, K. M. (2012). Impact of bureaucratic structure on the organizational performance of government organizations. [online]. Available at: http://ssrn.com/abstract=2042339. (10 August 2012).

Radermacher, H., Karunarathna, Y., Grace, N., \& Feldman S. (2011). Partner or perish? exploring inter-organisational partnerships in the multicultural community aged care sector. Health Social Care Community, 19 (5), 550-60.

Rajesh, R., Pugazhendhi, S., Ganesh, K., Ducq, Y., \& Lenny- Koh S.C. (2012). Generic balanced scorecard framework for third party logistics service provider. International Journal of Production Economics, 140 (1), 269-282.

Ramseook-Munhurrun, P., Lukea-Bhiwajee, S. D., \& Naidoo, P. (2010). Service quality in the public service. International Journal of Management and Marketing Research, 3 (1), 37-50.

Richard, O. C., Mcmillan, A., Chadwick, K., \& Dwyer, S. (2009). Employing an innovation strategy in racially diverse workforces: effects on firm performance. Group and Organisation Management, 28, 107-126.

Robinson, L. (2003). Committed to quality: the use of quality schemes in UK public leisure services. Managing Service Quality, 13 (3), $247-55$.

Robinson, E. J. H., Feinerman, O., \& Frank, N. R. (2009). Flexible task allocation and the organization of work in ants. Procedings of the Royal Society, 276, 4373-4380.

Samuel, M. O., \& Chipunza, C. (2009). Employee retention and turnover: using motivational variables as a panacea. African Journal of Business Management, 3 (8), 410-415.

Schalm, C. (2008). Implementing a balanced scorecard as a strategic management tool in a long-term care organisation. Journal of Health Services Research Policy, 13 (1), 8-14.

Schneiderman, A. M. (1999). Why Balanced Scorecards fail? Journal of Strategic Performance Measurement, January, Special Edition 6, $192-$ 217.

Schwella, E. (2001). Public sector policy in the New South Africa: a critical review. Public Performance \& Management Review, 24, (4), 367-38.

Seijts, G. H., \& Latham, G.P. (2005). Learning versus performance goals: when should each be used. Academy of Management Executive. 12, 124-131.

Serrat, O. (2010). Perils of performance management. Knowledge Solutions, 84, 1-8.

Short, J.C., Ketchen, D.J., Palmer, T.B., \& Hult G.T.M. (2007). Organization, strategic group and industry influences on performance. Strategic Management Journal, 28 (3), 147-167.

Speculand, R ., \& Chaudhary, R. (2008). Living organisational values: The Bridges Value Inculcation Model. Business Strategy Series, 9 (6), 1-8.

Sullivan, J. (2011). Developing a culture of speed - HR's role in increasing organizational speed.[online]. Available at: http://www.ere. net/2011/05/23/developing-a-culture-of-speed-hr\%E2\%80\%99s-role-in-increasing-organizational-speed. (5 December 2012).

Sydney, S. (2004). Using the Balanced Scorecard to measure Laboratory performance. Business Briefing: Labtech, 38-42.[online]. Available at: http://www.touchbriefings.com/pdf/953/sidney.pdf. (7 January 2013)

Tahir, S., Yusoff, R., Azam, K., Khan, A., \& Kaleem, S. (2012). The effects of work overload on the employees' performance in relation to customer satisfaction: A case of Water \& Power Development Authority, Attock, Pakistan. World Journal of Social Sciences, 2 (1), 174 181.

Tait, A., \& Nienaber, H. (2010). Exploring the strategy to process gap: the case of four South African life insurers. Journal of Contemporary Management, 7, 271-289.

Teicher, J., Hughes, O., \& Dow, N. (2002). E-government: a new route to public service quality, Managing Service Quality, 12 (6), $384-93$.

Thorne, K., \& Pellant, A. (2007). The essential guide to managing talent. London: Kogan Page.

University of New Mexico. (2011). Alternative work arrangements: including flexible schedules. [online]. Available at: http://hr.unm.edu /docs/employment/alternative-work-arrangements-including-flexible-schedules.pdf. (13 August 2012).

Van Der Heijden, T., \& Mlandi, M. (2005). Organisational success and failure in the public sector. Journal of Public Administration, 6(4), 20-22.

Wery, R., \& Waco, M. (2004). Why good strategies fail. Handbook of Business Strategy, 5(1), 153-157.

Wu, C. (2010). The relationship between corruptive contexts, organisational ethics practices and anti corruption performance on the two sides of the Taiwan Strait. Issues \& Studies, 46 (1), 147-187.

Wynder, M. (2010). Chemico: evaluating performance based on the Balanced Scorecard: Journal of Accounting Education, 28 (3), $221-236$.

Young, J. (2011). High performance and corporate culture. [online]. Available at: http://www.jasonyoungspeaks.com/JYoung_article.pdf. (12 June 2012).

Zairi, M., \& Jarrar, Y. (2000). Impact of organisational values on business performance. European Center for TQM. [online]. Avaliable at: http:// www. meqa.org /sites /default /files /Impact \%20of \%20 Organisational \% 20 Values\%20on\%20Business\%20Performance_0.pdf. (15 September 2012). 